\title{
Les mystères de la procession de Lille, édition critique par Alan E. Knight
}

\section{Maria Colombo Timelli}

\section{(2) OpenEdition}

10 Journals

\section{Édition électronique}

URL : http://journals.openedition.org/studifrancesi/32886

DOI : 10.4000/studifrancesi.32886

ISSN : 2421-5856

Éditeur

Rosenberg \& Sellier

\section{Édition imprimée}

Date de publication : 1 décembre 2005

Pagination : 619

ISSN : 0039-2944

\section{Référence électronique}

Maria Colombo Timelli, «Les mystères de la procession de Lille, édition critique par Alan E. Knight », Studi Francesi [En ligne], 147 (XLX | III) | 2005, mis en ligne le 30 novembre 2015, consulté le 20 avril 2021. URL : http://journals.openedition.org/studifrancesi/32886 ; DOI : https://doi.org/10.4000/ studifrancesi.32886

Ce document a été généré automatiquement le 20 avril 2021.

\section{(c)}

Studi Francesi è distribuita con Licenza Creative Commons Attribuzione - Non commerciale - Non opere derivate 4.0 Internazionale. 


\title{
Les mystères de la procession de Lille, édition critique par Alan E. Knight
}

\author{
Maria Colombo Timelli
}

\section{RÉFÉRENCE}

Les mystères de la procession de Lille, édition critique par ALAN E. KNIGHT. Tome III, De Salomon aux Macchabées, Genève, Droz, 2004 («Textes Littéraires Français», 569), 632 pp.

1 La publication des mystères transmis par le manuscrit Guelf. 9 Blankenburg de la Herzog August Bibliothek de Wolfenbüttel continue avec ce troisième volume (les deux premiers ont paru en 2001, «TLF» 535, cf. questi «Studi» 139, pp. 144-145; et en 2003, «TLF» 554, cf. questi «Studi» 146, pp. 406-407). Sont réunies ici les pièces 29 à 43, les dernières dont le sujet est tiré de l'Ancien Testament: Le couronnement de Salomon, Le jugement de Salomon, Elie et les prophètes de Baal, La vigne de Naboth, La mort du roi Achab, L'enlèvement d'Elie au ciel, La guérison de Naamân, Le siège de Samarie, L'histoire de Tobie, L'histoire de Suzanne, Judith et Holopherne, Esther et Assuérus, Judas Macchabée, Héliodore et le trésor du Temple, Darius et les trois jouvenceaux. L'édition est précédée d'une note concernant l'établissement du texte et de l'Errata du tome II; pour l'introduction générale au recueil, il faudra consulter le premier volume. Chaque mystère est présenté dans une notice succinte qui introduit le sujet, décrit la miniature qui accompagne le texte, analyse rapidement la versification; l'apparat critique est situé en bas de page, les notes explicatives suivant chaque pièce.

2 Le choix des sujets dans cette section du manuscrit semble obéir à un double principe: la variété de la matière, avec alternance entre pièces mouvementées (batailles, massacres, mort d'hommes) et scènes d'intérieur, où est surtout mise en relief la psychologie des personnages, et l'édification des spectateurs (leçons contre l'avarice, exaltation de la patience ou de l'obédience).

3 On attend maintenant les derniers résultats du gros travail d'édition entrepris par Alan E. Knight (les deux prochains volumes contiendront respectivement les mystères tirés 
du Nouveau Testament et ceux tirés de l'histoire romaine et du légendier chrétien), à féliciter pour le difficile équilibre qu'il a su tenir entre un texte imposant par sa longueur et par ses sources, et une édition lisible et néanmoins accompagnée d'une information scientifique rigoureuse. 